\title{
PEMULIHAN KUALITAS TANAH BEKAS TAMBANG BATUBARA MELALUI PENANAMAN Desmodium ovalifolium
}

\section{Soil Quality Improvement in Coal Ex-mining Land by Desmodium ovalifolium}

\author{
GINDO TAMPUBOLON ${ }^{1}$, ITANG A. MAHBUB ${ }^{1}$ dan MUHAMMAD I. LAGOWA ${ }^{2}$ \\ ${ }^{1}$ Fakultas Pertanian, Universitas Jambi \\ ${ }^{2}$ Fakultas Sains dan Teknologi, Universitas Jambi \\ Kampus Pinang Masak, Jl. Lintas Jambi-Muara Bulian Km.15, \\ Mendalo Darat, Jambi Luar Kota, Jambi 36122 \\ e-mail : unjagindo@yahoo.co.id
}

\begin{abstract}
ABSTRAK
Penutupan permukaan tanah dengan tanaman penutup (cover crop) merupakan salah satu langkah penting dalam pemulihan kualitas tanah bekas tambang batubara. Desmodium ovalifolium merupakan salah satu jenis tanaman penutup tanah (land cover crop) dari famili Leguminosae yang tidak menjalar dan melilit. Hasil analisis tanah bekas tambang batubara pada penelitian sebelumnya menunjukkan bahwa tanah tersebut

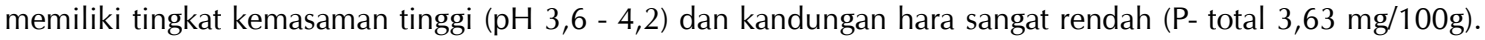
Dalam mengoptimalkan pertumbuhan $D$. ovalifolium pada kondisi tanah seperti demikian perlu dilakukan perbaikan lingkungan tumbuh $(\mathrm{pH}, \mathrm{P}$-tersedia dan ketersediaan unsur hara tanaman). Salah satu upaya perbaikan tanah adalah melalui pemberian kapur dolomit dan pupuk fosfat. Penelitian ini bertujuan untuk mempelajari pengaruh dosis kapur dolomit dan pupuk fosfat terhadap kemampuan $D$. ovalifolium dalam menutupi permukaan tanah dan menyumbang unsur hara N, P, K dan bahan organik pada tanah bekas tambang batubara. Penelitian ini menggunakan Rancangan Acak Kelompok dengan 12 perlakuan. Hasil penelitian menunjukkan bahwa kualitas tanah terbaik didapat pada pemberian 95,15 g dolomit dan $5 \mathrm{~g}$ Trisodium Phosphate Powder (TSP) per lubang tanam. Perlakuan tersebut mampu meningkatkan pH tanah dari 4,57 menjadi 6,5, menghasilkan berat kering pangkasan $D$. ovalifolium umur 3,5 bulan sebanyak 2149,84 $\mathrm{kg} / \mathrm{ha}(2,15 \mathrm{ton} / \mathrm{ha}), 1961,73 \mathrm{~kg} / \mathrm{ha}$ bahan organik, 41,66 kg/ha N, 6,32 kg/ha P dan 21,05 kg /ha $\mathrm{K}$ dengan persentase penutupan lahan $73.08 \%$.
\end{abstract}

Kata kunci: tanah bekas tambang batubara, pertumbuhan Desmodium, pengapuran, TSP

\begin{abstract}
Covering the soil surface using cover crops is a crucial step to recover the quality of a coal ex-mining land. Desmodium ovalivolium is a type of non-climbing and non-wrapping cover crop from the Leguminosae family. The result of soil analysis in the coal ex-mining land showed that the soil had high acid (pH 3.6- 4.2) condition and very low nutrient content (P-total of $3.63 \mathrm{mg} / 100 \mathrm{~g}$ ). Therefore, a soil quality improvement by treating it with dolomite and phosphate-based fertilizer such as Trisodium Phosphate Powder (TSP) is required for optimizing the growth of D. ovalivolium. This study was aimed to study the effect of dolomite and TSP dosage on the capacity of $D$. ovalifolium in covering soil surface as well as its nutrient contribution $(N, P$, and $K)$ and organic materials to the coal ex-mining land. The method used in this study was Randomizer Block Design with 12 treatments. The results showed that the best soil condition was yielded when using $95.15 \mathrm{~g}$
\end{abstract}


dolomite and $5 \mathrm{~g}$ TSP per planting hole. This treatment increased the soil $\mathrm{pH}$ from 4.57 to 6.5 , and after 3.5 months, the yielded dried pruned D.ovalifolium was 2149.84 kgs/acre (2.15 tonnes/acre) along with 1961.73 kgs/acre organic materials, $41.66 \mathrm{kgs} / \mathrm{acre} \mathrm{N}, 6.32 \mathrm{kgs} / \mathrm{acre} P$, and $21.05 \mathrm{kgs} / \mathrm{acre} \mathrm{K}$ and $73.08 \%$ surface covering.

Keywords: coal post-mining area, Desmodium growth, liming, TSP

\section{PENDAHULUAN}

Pada saat ini sebagian besar penambangan batubara dilakukan dengan metode tambang terbuka (open pit mining). Tahapan kegiatan meliputi pembukaan dan penyiapan lahan, pengupasan tanah pucuk (top soil), pengupasan tanah penutup (stripping overburden), penimbunan tanah penutup (overburden removal), penambangan batubara (coal getting) dan pengisian lubang tambang (backfilling).

Penambangan batubara secara terbuka mengakibatkan terjadinya penurunan kualitas tanah secara fisik, kimia dan biologi. Degradasi tanah antara lain ditandai dengan perubahan perlapisan tanah yaitu tanah pucuk bercampur dengan overburden dan terjadinya pemadatan tanah pada saat penimbunan kembali (Subowo, 2011).

Permasalahan pokok pada tanah bekas tambang batubara adalah gersang, padat, dan tidak bervegetasi sehingga rentan erosi (Widyati, 2008; Subowo, 2011; Simanjorang, 2017). Erosi akan memperburuk kualitas tanah lahan bekas tambang batubara. Penutupan permukaan lahan bekas tambang batubara dengan penanaman tanaman penutup tanah menjadi salah satu upaya memulihkan dan memperbaiki kualitas lingkungan (Ambodo, 2008). Fungsi penanaman tanaman penutup tanah adalah untuk mengurangi daya tumbuk butir hujan yang jatuh serta mengurangi debit dan kecepatan aliran permukaan yang pada akhirnya mengurangi erosi tanah (Arsyad, 2010).

Penutupan permukaan tanah dengan tanaman penutup tanah atau land cover crop berdampak positif terhadap ekosistem lahan bekas tambang batubara. Berbagai jenis tanaman penutup tanah dari jenis legum telah dikenal baik di perkebunan kelapa sawit yakni Calopogonium mucunoides, Pueraria javanica, Centrosema pubescens, dan Mucuna sp. (Saputra dan Wawan, 2017). Tanamantanaman tersebut tumbuh secara memanjat atau melilit, sehingga dapat mengganggu pertumbuhan tanaman di sekitarnya dan sulit diimplementasikan pada pola tanam jarak rapat seperti halnya di lahan reklamasi pasca tambang batubara. Alternatif yang dapat dikembangkan adalah tanaman yang tidak menjalar dan tidak melilit, seperti Desmodium ovalifolium.

Tanaman D. ovalifolium merupakan salah satu jenis tanaman legume, merayap, dengan geragih (stolon) dapat mencapai panjang $1 \mathrm{~m}$ di atas permukaan tanah (Halim dan Othman, 1982). Desmodium tumbuh baik dan mampu beradaptasi di tanah dengan kesuburan rendah, tanah asam dengan $\mathrm{Al}, \mathrm{Mn}$ tinggi, dan $P$ rendah (Schmidt, Peter dan Kraft, 2003).

Tala'ohu dan Erfandi (2013) menyatakan bahwa tanah bekas tambang batubara memiliki pH 3,5 (sangat masam), C-organik $0,05 \%$ (sangat rendah) dan $\mathrm{N}$-total $0,05 \%$ (sangat rendah). Hasil penelitian Simanjorang (2017) di area bekas tambang batubara PT. Nan Riang, Jambi memperlihatkan bahwa kemasaman tanah $(\mathrm{pH})$ berkisar antara 3,6-4,2 (sangat rendah), C-organik 0,08-1,58 \% (sangat rendah - rendah), P-total 3,63-20,36 $\mathrm{mg} / \mathrm{kg}$ (sangat rendah - sedang), dan kandungan Al-dd 4,6 sampai 6 me/100g.

Dalam mendukung pertumbuhan $D$. ovalifolium di tanah bekas tambang batubara, perlu dilakukan perbaikan lingkungan tumbuh yaitu dengan pemberian kapur dan fosfat. Salah satu jenis kapur yang biasa digunakan adalah dolomit. Pemberian kapur dolomit akan meningkatkan $\mathrm{pH}$ tanah, menurunkan kejenuhan $\mathrm{Al}$, serta meningkatkan $\mathrm{Ca}$ dan $\mathrm{Mg}$. Selain itu, pemberian kapur dapat memperbaiki sifat fisik dan biologi tanah. Hasil penelitian Ramadhan (2017) menunjukkan bahwa pemberian kapur dolomit dapat meningkatkan $\mathrm{pH}$ tanah dari 4,5 menjadi 5,6. Pertumbuhan bibit kelapa sawit terbaik dihasilkan pada dosis $1 \times \mathrm{Al}$-dd (15,80 ton/ha). Pemberian kapur $300 \mathrm{~kg} / \mathrm{ha}$ dapat meningkatkan serapan hara $\mathrm{P}, \mathrm{K}$ dan $\mathrm{Ca}$ tanaman ubi kayu masing-masing 68, 10, dan 
$113 \%$ dan jika dosis dolomit ditingkatkan sampai $600 \mathrm{~kg} / \mathrm{ha}$ maka serapan hara Ca meningkat $22 \%$ tetapi tidak mampu meningkatkan serapan hara (Ispandi dan Munip, 2005). Hasil penelitian Nurhalim (2018) menunjukkan bahwa total berat kering tajuk dan akar D. ovalifolium meningkat secara linear pada aplikasi dolomit $500 \mathrm{~kg} / \mathrm{ha}$ dan $1.000 \mathrm{~kg} / \mathrm{ha}$. Dijelaskan lebih lanjut bahwa pemberian kapur juga dapat meningkatkan serapan hara nitrogen dan fosfor.

D. ovalifolium dapat dipangkas 3-4 bulan setelah tanam dan hasil pangkasan dapat dijadikan sebagai sumber bahan organik. Produksi biomassa $D$. ovalifolium dapat mencapai 8,6 sampai 8,9 ton/ha, jauh lebih tinggi dibandingkan dengan biomassa $C$. moconoides dan C. Pubescens (Armecin $d k k$., 2005).

\section{METODE}

Penelitian ini menggunakan Rancangan Acak Kelompok dengan pola faktorial. Ukuran petak percobaan adalah 0,75 x 0,75 m dengan jarak tanam $40 \times 40 \mathrm{~cm}$. Dalam setiap petak percobaan terdapat 8 tanaman. Konsentrasi rata-rata Al-dd dari enam percontoh tanah di lokasi penelitian yaitu 6,36 me/100g tanah. Perlakuan meliputi pemberian kapur dolomit pada tanah yang tidak diberi TSP dan pada tanah yang diberi 5 gram TSP/lubang tanam.

Variasi perlakuan yang dilakukan, didasarkan kepada kandungan Al-dd dan kadar P tersedia di dalam tanah. Variasi penambahan dolomit dimulai dari tanpa dolomit, 50\% Al-dd, 100\% Al-dd, 150\% Al-dd, 200\% Al-dd, 250\% Al-dd. Berdasarkan ketentuan tersebut, rincian perlakuan yang dilakukan adalah: tanpa dolomit dan TSP/Lb; tanpa dolomit $+5 \mathrm{~g}$ TSP/Lb; 18,43 g dolomit tanpa TSP/Lb; 18,43 g dolomit + 5 g TSP/Lb; 36,86 g dolomit dan tanpa TSP/Lb; 36,86 g dolomit dan $5 \mathrm{~g}$ TSP/Lb; 55,29 g dolomit dan tanpa TSP/Lb; 55,29 g dolomit dan $5 \mathrm{~g}$ TSP/Lb; 73,72 g dolomit dan tanpa TSP/Lb; 73,72 g dolomit dan 5 g TSP/Lb; 92,15 g dolomit dan tanpa TSP/Lb; serta 92,15 g dolomit dan 5 g TSP/Lb.
Variabel yang diamati terdiri dari persen penutupan lahan, berat brangkasan basah, berat brangkasan kering, berat kering akar, berat bintil akar, jumlah bintil akar, persentase akar efektif serta $\mathrm{pH}$ dan C-organik. Seluruh data dianalisis dengan menggunakan analisis ragam dan dilanjutkan dengan Uji Jarak Berganda Duncan 5\%.

\section{HASIL DAN PEMBAHASAN}

Hasil analisis ragam menunjukkan bahwa perlakuan berpengaruh nyata terhadap $\mathrm{pH}$ tanah dan C-organik, namun berpengaruh tidak nyata terhadap persen penutupan lahan, berat brangkasan basah, berat brangkasan kering, berat kering akar, berat bintil akar, dan jumlah bintil akar persentase akar efektif (Tabel 1).

Dari Tabel 2 dan 3 tampak bahwa perlakuan dolomit dan TSP sangat nyata meningkatkan $\mathrm{pH}$ tanah. Peningkatan $\mathrm{pH}$ tanah terjadi karena dolomit $\left(\mathrm{CaMg}\left(\mathrm{CO}_{3}\right)_{2}\right)$ yang diaplikasikan terurai menghasilkan ion $\mathrm{Ca}^{2+}, \mathrm{Mg}^{2+}$ dan ion $\mathrm{CO}_{3}{ }^{2-}$. Selanjutnya, $\mathrm{CO}_{3}{ }^{2-}$ yang terbentuk menarik $\mathrm{H}^{+}$dari kompleks jerapan membentuk $\mathrm{HCO}_{3}{ }^{-}$. Lebih lanjut, ion $\mathrm{Ca}^{2+}$ dan $\mathrm{Mg}^{2+}$ segera mengisi kompleks jerapan (Kussow, 1971). Peningkatan $\mathrm{pH}$ tanah akan berpengaruh terhadap serapan unsur hara, yang selanjutnya meningkatkan jumlah bintil akar efektif dan pertumbuhan vegetatif $D$. ovalifolium walaupun berbeda tidak nyata dengan kontrol. Peningkatan $\mathrm{pH}$ tanah juga meningkatkan efektifitas pemfiksasian $\mathrm{N}_{2}$ oleh bintil akar kedelai (Lubis, Hanafiah dan Sembiring, 2015). Dolomit dan pupuk kandang bersama-sama dapat memperbaiki sifat kimia tanah yaitu $\mathrm{pH}$ tanah dan N-total tanah, serta meningkatkan hasil kacang tanah (Syahrizal, Sahari dan Haryanto, 2014). Pemberian bahan organik juga berpengaruh sangat nyata dan terbaik pada pemberian 92,15 g dolomit dan $5 \mathrm{~g}$ TSP/lubang tanam yaitu 3,76 \% (kriteria tinggi) yang berbeda nyata dengan perlakuan tanpa dolomit dan pemberian dolomit sampai dosis 36,86 g dolomit tanpa TSP dan dengan $5 \mathrm{~g}$ TSP/lubang tanam. Kandungan C-organik tanah lebih disebabkan oleh pengaruh media dari bibit dan pemberian $0,5 \mathrm{~kg}$ kompos kotoran ayam tiap lubang tanam. 
Tabel 1. Hasil analisis ragam pengaruh perlakuan dolomit dan TSP terhadap variabel tanah dan tanaman $D$. ovalifolium

\begin{tabular}{llcccc}
\hline \multirow{2}{*}{ No } & \multirow{2}{*}{ Variabel } & \multirow{2}{*}{ F-hitung } & \multicolumn{2}{c}{ F-Tabel } & \multirow{2}{*}{ Keterangan } \\
\cline { 3 - 4 } & & $5 \%$ & $1 \%$ & \\
\hline 1 & pH & $3,58^{* *}$ & 2,09 & 2,84 & Berpengaruh Sangat Nyata \\
2 & Bahan organik tanah & $6,06^{* *}$ & 2,09 & 2,84 & Berpengaruh Sangat Nyata \\
3 & Presentase penutupan lahan & $0,87^{\text {tn }}$ & 2,09 & 2,84 & Tidak nyata \\
4 & Berat brangkasan basah & $1,06^{\text {tn }}$ & 2,09 & 2,84 & Tidak nyata \\
5 & Berat brangkasan kering & $1,03^{\text {tn }}$ & 2,09 & 2,84 & Tidak nyata \\
6 & Berat kering akar & $0,91^{\text {tn }}$ & 2,09 & 2,84 & Tidak nyata \\
7 & Bobot bintil akar & $1,38^{\text {tn }}$ & 2,09 & 2,84 & Tidak nyata \\
8 & Jumlah bintil akar & $1,14^{\text {tn }}$ & 2,09 & 2,84 & Tidak nyata \\
9 & Bintil akar efektif $(\%)$ & $0,77^{\text {tn }}$ & 2,09 & 2,84 & Tidak nyata \\
\hline
\end{tabular}

Tabel 2. Hasil Duncan Multiple Range Test (DMRT) pengaruh perlakuan dolomit dan TSP terhadap variabel $\mathrm{pH}$, bahan organik, PPL, BBB, dan BBK

\begin{tabular}{llccccc}
\hline \multirow{2}{*}{ Notasi } & \multirow{2}{*}{ Perlakuan } & \multicolumn{5}{c}{ Variabel } \\
\cline { 3 - 6 } & & $\mathrm{pH}$ & $\begin{array}{c}\text { Bahan organik } \\
(\%)\end{array}$ & PPL (\%) & BBB (g) & BBK (g) \\
\hline d0p0 & Tanpa dolomit dan TSP/Lb & $4,57 \mathrm{~d}$ & $2,49 \mathrm{~d}$ & $61.57 \mathrm{a}$ & $311.62 \mathrm{a}$ & $94.53 \mathrm{a}$ \\
d0p1 & Tanpa dolomit + 5 g TSP/Lb & $4,92 \mathrm{~cd}$ & $2,70 \mathrm{~cd}$ & $61.08 \mathrm{a}$ & $305.99 \mathrm{a}$ & $90.82 \mathrm{a}$ \\
d1p0 & 18,43 g dolomit tanpa TSP/Lb & $4,96 \mathrm{~cd}$ & $2,91 \mathrm{~cd}$ & $73.60 \mathrm{a}$ & $422.02 \mathrm{a}$ & $123.68 \mathrm{a}$ \\
d1p1 & 18,43 g dolomit + 5 g TSP/Lb & $5,63 \mathrm{abc}$ & $2,78 \mathrm{~cd}$ & $69.68 \mathrm{a}$ & $439.23 \mathrm{a}$ & $132.16 \mathrm{a}$ \\
d2p0 & 36,86 g dolomit dan tanpa TSP/Lb & $5,32 \mathrm{bcd}$ & $2,76 \mathrm{~cd}$ & $68.94 \mathrm{a}$ & $389.02 \mathrm{a}$ & $113.44 \mathrm{a}$ \\
d2p1 & 36,86 g dolomit dan 5 g TSP/Lb & $5,54 \mathrm{bcd}$ & $2,87 \mathrm{~cd}$ & $73.71 \mathrm{a}$ & $429.41 \mathrm{a}$ & $126.96 \mathrm{a}$ \\
d3p0 & 55,29 g dolomit dan tanpa TSP/Lb & $5,01 \mathrm{~cd}$ & $3,64 \mathrm{a}$ & $69.92 \mathrm{a}$ & $293.25 \mathrm{a}$ & $89.08 \mathrm{a}$ \\
d3p1 & 55,29 g dolomit dan 5 g TSP/Lb & $5,44 \mathrm{bcd}$ & $3,64 \mathrm{a}$ & $74.15 \mathrm{a}$ & $463.05 \mathrm{a}$ & $140.35 \mathrm{a}$ \\
d4p0 & 73,72 g dolomit dan tanpa TSP/Lb & $4,99 \mathrm{~cd}$ & $3,03 \mathrm{bcd}$ & $69.27 \mathrm{a}$ & $324.27 \mathrm{a}$ & $91.91 \mathrm{a}$ \\
d4p1 & 73,72 g dolomit dan 5 g TSP/Lb & $5,03 \mathrm{~cd}$ & $3,22 \mathrm{abc}$ & $64.51 \mathrm{a}$ & $336.02 \mathrm{a}$ & $99.33 \mathrm{a}$ \\
d5p0 & 92,15 g dolomit dan tanpa TSP/Lb & $6,14 \mathrm{ab}$ & $3,52 \mathrm{ab}$ & $76.82 \mathrm{a}$ & $408.40 \mathrm{a}$ & $125.20 \mathrm{a}$ \\
d5p1 & 92,15 g dolomit dan 5 g TSP/Lb & $6,51 \mathrm{a}$ & $3,76 \mathrm{a}$ & $73.08 \mathrm{a}$ & $471.25 \mathrm{a}$ & $137.59 \mathrm{a}$ \\
\hline
\end{tabular}

Tabel 3. Hasil DMRT pengaruh perlakuan dolomit pada tanah bekas tambang batubara yang tidak diberikan TSP dan diberi $5 \mathrm{~g}$ TSP / lubang tanam terhadap variabel BKA, BBA, JBA, dan PAE

\begin{tabular}{|c|c|c|c|c|c|}
\hline \multirow{2}{*}{ Notasi } & \multirow{2}{*}{ Perlakuan } & \multicolumn{4}{|c|}{ Variabel } \\
\hline & & $\mathrm{BKA}(\mathrm{g})$ & $\mathrm{BBA}(\mathrm{g})$ & $\mathrm{JBA}$ & PAE (\%) \\
\hline d0p0 & Tanpa dolomit dan TSP/Lb & $6,55 a b$ & $5,14 a b$ & $377,25 \mathrm{a}$ & $68,38 \mathrm{a}$ \\
\hline d0p1 & Tanpa dolomit + 5 g TSP/Lb & $5,70 a b$ & $6,35 a b$ & $818,25 \mathrm{a}$ & $67,93 \mathrm{a}$ \\
\hline $\mathrm{d} 1 \mathrm{p} 0$ & 18,43 g dolomit tanpa TSP/Lb & $7,58 \mathrm{ab}$ & $4,74 \mathrm{~b}$ & $343,50 \mathrm{a}$ & $65,67 \mathrm{a}$ \\
\hline d1p1 & 18,43 g dolomit + 5 g TSP/Lb & $7,08 \mathrm{ab}$ & $8,56 \mathrm{ab}$ & $803,00 \mathrm{a}$ & $73,59 \mathrm{a}$ \\
\hline $\mathrm{d} 2 \mathrm{p} 0$ & 36,86 g dolomit dan tanpa TSP/Lb & $6,83 \mathrm{ab}$ & $3,83 \mathrm{~b}$ & $255,50 \mathrm{a}$ & $66,62 \mathrm{a}$ \\
\hline $\mathrm{d} 2 \mathrm{p} 1$ & 36,86 g dolomit dan 5 g TSP/Lb & $8,53 \mathrm{a}$ & $6,30 \mathrm{ab}$ & $530,25 \mathrm{a}$ & $63,64 \mathrm{a}$ \\
\hline $\mathrm{d} 3 \mathrm{p} 0$ & 55,29 g dolomit dan tanpa TSP/Lb & $4,58 \mathrm{~b}$ & $5,02 \mathrm{ab}$ & $551,00 \mathrm{a}$ & $79,93 \mathrm{a}$ \\
\hline d3p1 & 55,29 g dolomit dan $5 \mathrm{~g}$ TSP/Lb & $6,40 a b$ & $10,77 \mathrm{a}$ & $833,75 \mathrm{a}$ & $76,22 \mathrm{a}$ \\
\hline $\mathrm{d} 4 \mathrm{p} 0$ & 73,72 g dolomit dan tanpa TSP/Lb & $7,60 \mathrm{ab}$ & $4,28 \mathrm{~b}$ & $310,75 \mathrm{a}$ & $63,48 \mathrm{a}$ \\
\hline $\mathrm{d} 4 \mathrm{p} 1$ & 73,72 g dolomit dan 5 g TSP/Lb & $6,63 \mathrm{ab}$ & $4,97 \mathrm{ab}$ & $341,00 \mathrm{a}$ & $64,20 \mathrm{a}$ \\
\hline $\mathrm{d} 5 \mathrm{p} 0$ & 92,15 g dolomit dan tanpa TSP/Lb & $8,43 a b$ & $3,81 \mathrm{~b}$ & $294,25 \mathrm{a}$ & $72,61 \mathrm{a}$ \\
\hline $\mathrm{d} 5 \mathrm{p} 1$ & 92,15 g dolomit dan $5 \mathrm{~g}$ TSP/Lb & $6,75 \mathrm{ab}$ & $6,66 \mathrm{ab}$ & $461,00 \mathrm{a}$ & $68,77 \mathrm{a}$ \\
\hline
\end{tabular}

Keterangan: Angka-angka dalam setiap kolom yang diikuti oleh huruf yang sama menunjukkan tidak berbeda nyata pada uji DMRT $5 \%$.

PPL : Persentase penutupan lahan ; BBB : Berat brangkasan basah; BBK : Berat brangkasan kering; BKA : Berat kering akar; BBA : Bobot bintil akar; JBA : Jumlah bintil akar; PAE : Persen akar efektif

Hasil sidik ragam menunjukkan bahwa pemberian dolomit pada tanah yang tidak diberikan TSP dan diberi 5 g TSP per lubang tanam berpengaruh tidak nyata terhadap 
persentase penutupan lahan, berat brangkasan basah, berat brangkasan kering, berat kering segar, bobot bintil akar, jumlah bintil akar dan persen akar efektif. Begitu juga halnya dengan hasil DMRT $5 \%$ berbeda tidak nyata di antara perlakuan terhadap persentase penutupan lahan, berat brangkasan basah, berat brangkasan kering, berat kering segar, bobot bintil akar, jumlah bintil akar dan persen akar efektif.

Persentase penutupan lahan tertinggi pada akhir penelitian $(3,5$ bulan setelah tanam) terdapat pada plot dengan 92,15 g dolomit dan tanpa TSP/lubang tanam yakni $76.82 \%$ dan terendah pada perlakuan tanpa dolomit dan 5 g TSP/lubang tanam yakni $61.08 \%$. Grafik perkembangan persen penutupan lahan oleh tanaman $D$. ovalifolium dengan selang waktu pengukuran 2 minggu disajikan pada Gambar 1.

Dari Gambar 1 tampak bahwa perkembangan penutupan lahan tercepat terjadi pada waktu 2 minggu setelah tanam (pengukuran 1) untuk semua perlakuan dan pada waktu antara 12 minggu sampai 13 minggu setelah tanam. Antara pengukuran ke 2 sampai pengukuran ke 6 pertambahan persentase penutupan lahan agak lambat. Hal ini diduga akibat kondisi cuaca kering (musim kemarau) dengan curah hujan rendah dan suhu lingkungan tinggi, sehingga tanaman mengalami cekaman air walaupun dilakukan penyiraman. Tanah bekas tambang batubara umumnya gersang sehingga vegetasi sulit tumbuh, dan pada saat terjadi hujan air sulit meresap ke dalam tanah atau sebagian besar mengalir di permukaan tanah.

Permukaan tanah bekas tambang batubara yang telah tertutup oleh tajuk tanaman $D$. ovalifolium akan meminimalkan energi kinetik hujan dalam memukul permukaan tanah dan menghambat aliran air permukaan (run-off) dan menyebabkan air yang masuk ke dalam tanah meningkat sehingga erosi tanah menurun dan ekosistem lingkungan turut diperbaiki. Semakin banyak permukaan tanah yang ditutupi oleh vegetasi akan semakin baik dalam melindungi tanah dari proses erosi.

Perlakuan kapur dan TSP tidak berpengaruh nyata terhadap berat brangkasan kering. Berat brangkasan tertinggi terdapat pada perlakuan pemberian 95,15 g dolomit dan $5 \mathrm{~g}$ TSP/lubang tanam yakni 137, 59 g dan terendah pada perlakuan $55,29 \mathrm{~g}$ dolomit dan tanpa TSP/lubang tanam yakni 89,08 g dari 4 tanaman dengan jarak tanam $40 \times 40 \mathrm{~cm}$. Tajuk tanaman $D$. ovalifolium menjadi sumber bahan organik, unsur hara N, P dan K dalam pemulihan tanah bekas tambang batubara. Kontribusi tajuk D. ovalifolium dalam menyumbangkan bahan organik, N, P dan $\mathrm{K}$ disajikan dalam Tabel 4.

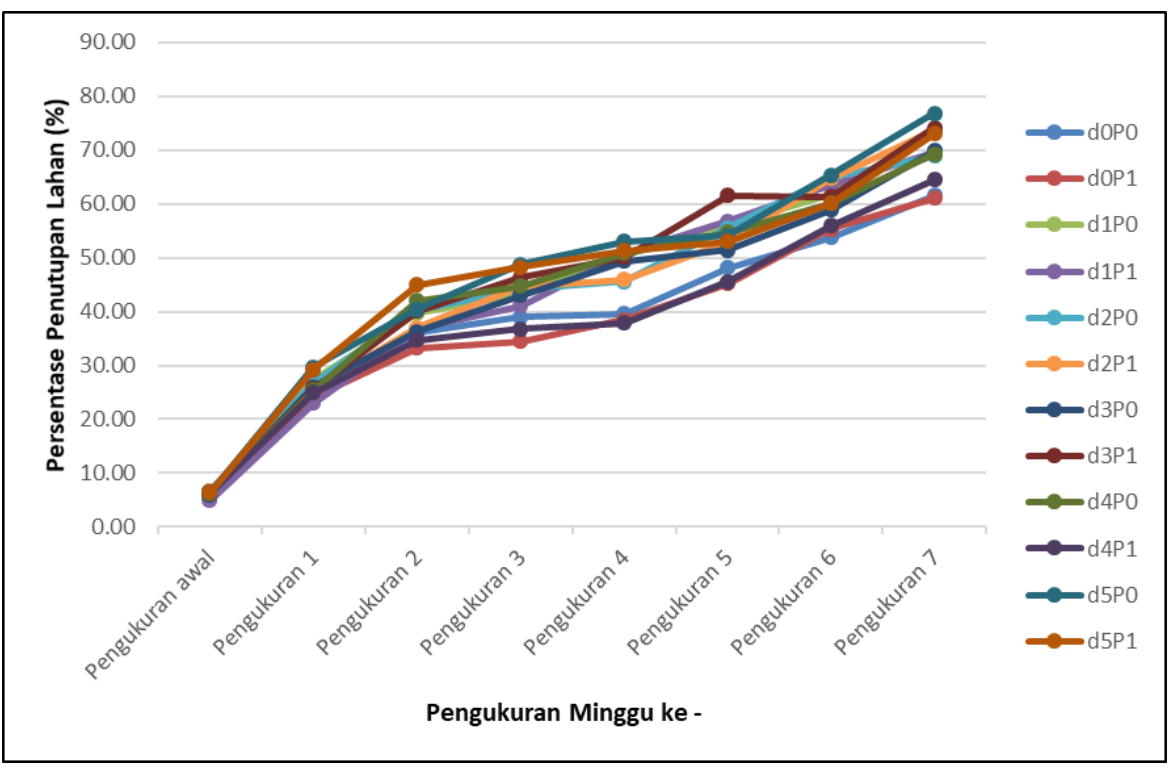

Gambar 1. Perkembangan persentase penutupan lahan oleh tanaman D. ovalifolium 
Tabel 4. Kontribusi tajuk D. ovalifolium dalam menyumbangkan bahan organik, N, P dan K

\begin{tabular}{|c|c|c|c|c|c|c|c|}
\hline \multirow{3}{*}{ Notasi } & \multirow{3}{*}{ Perlakuan } & \multirow{2}{*}{ BKP } & \multirow{2}{*}{ BKP } & \multirow{2}{*}{$\mathrm{BO}$} & \multicolumn{3}{|c|}{ Sumbangan hara } \\
\hline & & & & & $\mathrm{N}$ & $\mathrm{P}$ & $\mathrm{K}$ \\
\hline & & g/4 tanaman & (kg/ha) & (kg/ha) & \multicolumn{3}{|c|}{ (kg/ha) } \\
\hline $\mathrm{d} 0 \mathrm{p} 0$ & Tanpa dolomit dan TSP/Lb & 94,53 & 1476,99 & 1347,76 & 26,41 & 4,28 & 13,72 \\
\hline d0p1 & Tanpa dolomit $+5 \mathrm{~g}$ TSP/Lb & 90,82 & 1419,06 & 1294,89 & 25,38 & 4,12 & 13,18 \\
\hline $\mathrm{d} 1 \mathrm{p} 0$ & 18,43 g dolomit tanpa TSP/Lb & 123,68 & 1932,42 & 1770,58 & 35,96 & 5,10 & 17,35 \\
\hline $\mathrm{d} 1 \mathrm{p} 1$ & 18,43 g dolomit +5 g TSP/Lb & 132,16 & 2064,92 & 1891,98 & 38,43 & 5,45 & 18,54 \\
\hline $\mathrm{d} 2 \mathrm{p} 0$ & 36,86 g dolomit dan tanpa TSP/Lb & 113,44 & 1772,42 & 1635,06 & 31,38 & 7,70 & 16,02 \\
\hline $\mathrm{d} 2 \mathrm{p} 1$ & 36,86 g dolomit dan 5 g TSP/Lb & 126,96 & 1983,67 & 1829,94 & 35,12 & 8,62 & 17,93 \\
\hline $\mathrm{d} 3 \mathrm{p} 0$ & 55,29 g dolomit dan tanpa TSP/Lb & 89,08 & 1391,91 & 1250,98 & 26,02 & 5,08 & 10,58 \\
\hline d3p1 & 55,29 g dolomit dan $5 \mathrm{~g}$ TSP/Lb & 140,35 & 2192,97 & 1970,93 & 40,99 & 8,01 & 16,67 \\
\hline $\mathrm{d} 4 \mathrm{p} 0$ & $73,72 \mathrm{~g}$ dolomit dan tanpa TSP/Lb & 91,91 & 1436,05 & 1324,76 & 25,77 & 4,11 & 11,80 \\
\hline $\mathrm{d} 4 \mathrm{p} 1$ & 73,72 g dolomit dan $5 \mathrm{~g}$ TSP/Lb & 99,33 & 1551,99 & 1431,71 & 27,85 & 4,44 & 12,75 \\
\hline $\mathrm{d} 5 \mathrm{p} 0$ & 92,15 g dolomit dan tanpa TSP/Lb & 125,20 & 1956,21 & 1785,04 & 37,91 & 5,75 & 19,15 \\
\hline $\mathrm{d} 5 \mathrm{p} 1$ & 95,15 g dolomit dan $5 \mathrm{~g}$ TSP/Lb & 137,59 & 2149,84 & 1961,73 & 41,66 & 6,32 & 21,05 \\
\hline
\end{tabular}

Keterangan: BKP : Berat kering pupus; $\quad$ BO : Bahan organik

Berat kering brangkasan tertinggi terdapat pada perlakuan dengan pemberian 95,15 g dolomit dan $5 \mathrm{~g}$ TSP/lubang tanam yaitu $2149,84 \mathrm{~kg} / \mathrm{ha}$ atau setara dengan 2,15 ton/ha (Tabel 4). Berat brangkasan ini masih tergolong rendah dibandingkan dengan potensi $D$. ovalifolium yang menyebutkan bahwa produksi biomassa D. ovalifolium dapat mencapai 8,6 sampai 8,9 ton/ha, jauh lebih tinggi dibandingkan dengan biomassa yang dihasilkan dari C. moconoides dan C. pubescens pada tanah normal.

Kontribusi bahan organik, $\mathrm{N}$ dan $\mathrm{K}$ tertinggi terdapat pada perlakuan dengan pemberian 95,15 g dolomit dan 5 g TSP/lubang tanam, sedangkan kontribusi $\mathrm{P}$ tertinggi didapatkan pada perlakuan 36,86 g dolomit dan $5 \mathrm{~g}$ TSP/lubang tanam. Pengikatan (fiksasi) nitrogen dari udara dilakukan oleh bintil akar efektif yang terdapat pada tanaman. Persentase bintil akar efektif tertinggi terdapat pada perlakuan pemberian 55,29 g dolomit dan tanpa TSP/lubang tanam yaitu 79,93 \% sedangkan persentase terendah dihasilkan pada pemberian 73,72 g dolomit dan tanpa TSP/lubang tanam yaitu $63,48 \%$.

Pada perlakuan dolomit dan 5 g TSP/lubang tanam, persentase penutupan lahan, berat brangkasan basah, berat brangkasan kering, berat kering segar, bobot bintil akar, jumlah bintil akar dan persen akar efektif berbeda tidak nyata dengan pada perlakuan dolomit dan tanpa TSP. Dalam kurun waktu 3,5 bulan, pengaruh media tanam bibit $D$. ovalifolium berupa campuran top soil dan pupuk kandang kotoran ayam masih tampak, akan tetapi dalam kurun waktu yang lebih lama $(>3,5$ bulan) diduga efek pemberian dolomit dan TSP terhadap parameter di atas akan lebih tampak dibandingkan pengaruh media tanam.

\section{KESIMPULAN DAN SARAN}

Berdasarkan hasil penelitian disimpulkan bahwa pemberian 95,15 g dolomit dan $5 \mathrm{~g}$ TSP/lubang tanam mampu meningkatkan $\mathrm{pH}$ tanah dari 4,57 menjadi 6,51 dibandingkan dengan tanpa pemberian dolomit tanpa TSP serta meningkatkan bahan organik tanah dari 2,49\% menjadi 3,76\%.

D. ovalifolium dapat tumbuh dengan baik di tanah bekas tambang batubara dengan persen penutupan lahan tertinggi pada pemberian 92,15 g dolomit dan tanpa TSP/lubang tanam yakni $76.82 \%$ dan menghasilkan 2149,84 $\mathrm{kg} / \mathrm{ha}(2,150$ ton/ha). D. ovalifolium dapat dijadikan sebagai salah satu amelioran dalam memulihkan kualitas tanah bekas tambang batubara dengan kontribusi bahan organik, $\mathrm{N}$ dan $\mathrm{K}$ tertinggi pada perlakuan pemberian 95,15 g dolomit dan $5 \mathrm{~g}$ TSP/lubang tanam. Sedangkan kontribusi $P$ tertinggi diperoleh pada perlakuan pemberian 36,86 g dolomit dan $5 \mathrm{~g}$ TSP/lubang tanam.

Disarankan untuk melakukan pemantauan terhadap pertumbuhan kembali (regrowth) $D$. ovalifolium setelah pemangkasan dan melakukan penelitian pengomposan hasil pangkasan $D$. ovalifolium serta uji kualitas kompos. Selanjutnya dapat dilakukan pula 
penelitian aplikasi kompos tersebut terhadap perbaikan kualitas tanah dan pertumbuhan tanaman.

\section{UCAPAN TERIMA KASIH}

Penulis mengucapkan terimakasih kepada Universitas Jambi yang telah mendanai penelitian ini. Ucapan terima kasih juga ditujukan kepada PT. Nan Riang yang telah menyediakan lahan penelitian dan bantuan teknis selama penelitian serta civitas academica Program Studi Ilmu Tanah Jurusan Agroteknologi Universitas Jambi yang telah membantu pelaksanaan penelitian dan analisis hasil penelitian di laboratorium.

\section{DAFTAR PUSTAKA}

Ambodo, A. (2008) "Rehabilitasi lahan pasca tambang sebagai inti dari rencana penutupan tambang," in Seminar dan Workshop Reklamasi dan Pengelolaan Kawasan Pasca Penutupan Tambang. Makassar.

Armecin, R. B., Seco, M. H. P., Caintic, P. S. dan Milleza, E. J. M. (2005) "Effect of leguminous cover crops on the growth and yield of abaca (Musa textilis Nee)," Industrial Crops and Products, 21(3), hal. 317-323. doi: 10.1016/j.indcrop.2004.04.028.

Arsyad, S. (2010) Konservasi tanah dan air. Bogor: IPB Press.

Halim, R. A. dan Othman, S. (1982) "Establishment of desmodium ovalifolium on an ultisol," Pertanika, 5(1), hal. 53-57.

Ispandi, A. dan Munip, A. (2005) "Efektifitas pengapuran terhadap serapan hara dan produksi beberapa klon ubikayu di lahan kering masam," Ilmu Pertanian, 12(2), hal. 125-139.

Kussow, W. (1971) Introduction to soil chemistry. Institut Pertanian Bogor.

Lubis, D. S., Hanafiah, A. S. dan Sembiring, M. (2015) "Pengaruh $\mathrm{pH}$ terhadap pembentukan bintil akar, serapan hara $\mathrm{N}, \mathrm{P}$ dan produksi tanaman pada beberapa varietas kedelai pada tanah inseptisol di rumah kasa," Jurnal Agroekoteknologi, 3(3), hal. 1111-1115.

Nurhalim, S. (2018) Pengaruh pemberian kapur dolomit terhadap kontribusi Desmodium ovalifolium dalam menyumbangkan unsur hara $N, P, K$ dan bahan organik pada lahan bekas tambang batubara. Universitas Jambi.

Ramadhan, M. (2017) Respon pertumbuhan bibit kelapa sawit (Elais guinensis Jacq.) terhadap pemberian kapur dolomit, pupuk dan bakteri pereduksi sulfat pada tanah sulfat masam di rumah kaca. Universitas Sumatera Utara.

Saputra, A. dan Wawan (2017) "Pengaruh Leguminosa cover crop (LCC) Mucuna bracteata pada tiga kemiringan lahan terhadap sifat kimia tanah dan perkembangan akar kelapa sawit belum menghasilkan," JOM FAPERTA, 4(2), hal. 1-15.

Schmidt, A., Peter, M. dan Kraft, R. (2003) Desmodium heterocarpon (L.) DC subsp.ovalifolium (Prain) H. Ohashi : Species description.

Simanjorang, B. (2017) Evaluasi kesesuaian lahan beberapa jenis tanaman di areal reklamasi pasca tambang batubara (Studi kasus di PT. Nan Riang, Desa Ampelu Mudo, Kecamatan Muara Tembesi, Kabupaten Batanghari). Universitas Jambi.

Subowo, G. (2011) "Penambangan sistem terbuka ramah lingkungan dan upaya reklamasi pasca tambang untuk memperbaiki kualitas sumberdaya lahan dan hayati tanah," Jurnal Sumberdaya Lahan, 5(2), hal. 83-94.

Syahrizal, L., Sahari, P. dan Haryanto, E. (2014) "Tingkat kesuburan tanah ultisol pengaruh dosis pupuk organik dan dolomit terhadap pertumbuhan dan hasil tanaman kacang tanah," Jurnal Agrosains, 16(1), hal. 25-28.

Tala'ohu, S. H. dan Erfandi, D. (2013) "Inovasi teknologi penanggulangan masalah salinitas pada lahan timbunan pasca penambangan batubara," in Prosiding Seminar Nasional Matematika, Sains, dan Teknologi, hal. B.11B.21.

Widyati, E. (2008) "Peranan mikroba tanah pada kegiatan rehabilitasi lahan bekas tambang," Info Hutan, V(2), hal. 151-160. 
